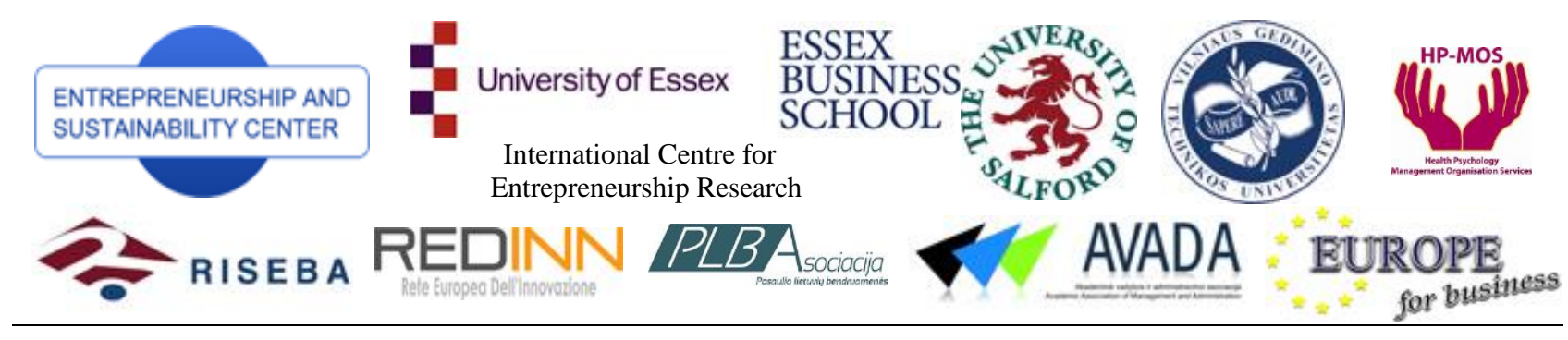

ENTREPRENEURSHIP AND SUSTAINABILITY ISSUES

ISSN 2345-0282 (online) http://jssidoi.org/jesi/aims-and-scope-of-research/

\title{
SUSTAINABLE ENTREPRENEURSHIP: THE WOLF BUTTERBACK CASE
}

\author{
Mike Wahl \\ Tallinn School of Economics and Business Administration, Tallinn University of Technology \\ Akadeemia tee 3-365, 12618 Tallinn, Estonia \\ E-mail:mike.wahl@ttu.ee
}

Received 15 February 2014; accepted 20 May 2014

\begin{abstract}
The overarching goal of strategic management is creating and capturing value for core stakeholders. Strategic audit enables a systematic analysis to be made of various corporate functions and activities. The Wolf ButterBack case is especially designed for using the Wheelen and Hunger (2012) case method, providing the opportunity to move from a narrow, specialized view that emphasizes functional techniques to a broader, less precise analysis of the overall corporation. Its strengths include a real-world orientation and the ability to focus on developing decision-making skills. This case study confirms the importance of value based sustainable entrepreneurship. Sustainable management is an unwritten law at Wolf ButterBack. Their entrepreneurial vision has never only focused on short-term profit maximisation but always on the company's long-term survival. The values that were the heart and soul of the company in that tiny garage in Stein are still valid today: Passion for the highest quality, focus on what is important and sustainable and, above all, closeness to customers. The case study is limited by the lack of financial information; this is typical for family owned firms where statements are delivered only to family members. It is recommended that further research should include evolutionary approaches, which are not explicitly used as a theoretical framework in strategic management, although the evolutionary perspective is consistent with it.
\end{abstract}

Keywords: case analysis methodology, strategic audit, strategic management, sustainable entrepreneurship, values

Reference to this paper should be made as follows: Wahl, M. 2014. Sustainable Entrepreneurship: The Wolf ButterBack Case, Entrepreneurship and Sustainability Issues 1(4): 223-229.

DOI: http://dx.doi.org/10.9770/jesi.2014.1.4(4)

JEL Classifications: A23, M14

\section{Introduction}

Strategy is defined as a series of goal-directed plans and activities that align a business's structure (chain of command), culture (beliefs, expectations, norms and values), and resources (tangible and intangible assets, skills, competencies, knowledge e.g. Laužikas, Mokšeckienè 2013; Korsakienè 2013; Tvaronavičienė 2014; Laužikas, Krasauskas 2013; Korsakienè and Tvaronavičiene 2014) with the opportunities and threats in its environment (Wahl, Prause 2013; Tvaronavičienė 2014). Nickerson et al. (2012) problem-finding and problem-solving approach considers four activities: problem finding, framing, and formulating; problem solving; solution implementation; and operating implemented solutions, as necessary for creating and capturing value. Strategic audit provides a checklist of questions, by area or issue that enables a systematic analysis to be made of various corporate functions and activities. It forces the student to do a complete strategic analysis as in the comprehensive report, but it is only a three to five-page outline and is thus quick to read and easy to grade. The case method provides the opportunity to move from a narrow, specialized view that 
emphasizes functional techniques to a broader, less precise analysis of the overall corporation. The most popular as well as the most perceived effective approach to teaching strategic management is the case method. Its strengths include a real-world orientation and the ability to focus on developing decision-making skills by taking an integrative and conceptual, yet action-oriented approach. The following Wolf ButterBack case is especially designed for using the Wheelen and Hunger (2012) case method in teaching strategic management.

The present paper is organised as follows. Section 2, "The Wolf ButterBack case" begins with historical description from entrepreneurial beginning in a tiny garage, followed by modernising, sustainable growth and internationalisation. Sustainable management and values are the heart and soul of the company until today. Section 3, "Conclusions and recommendations" concludes by describing the main insights.

\section{The Wolf ButterBack Case}

\subsection{It All Began in a Garage}

It all started at a meeting between Franconian master baker Erwin Wolf and his former colleague Dagmar Kreis in the summer of 1991. Deep-frozen pastries had already been on the market for several years. Erwin Wolf was of the firm belief that, if they were to do justice to a baker's product range, these deep-frozen products had to match, if not surpass the taste, appearance and high, hand-crafted quality achieved by a baker. Dagmar Kreis shared this passion and so they joined forces and established a new company named Wolf ButterBack KG.

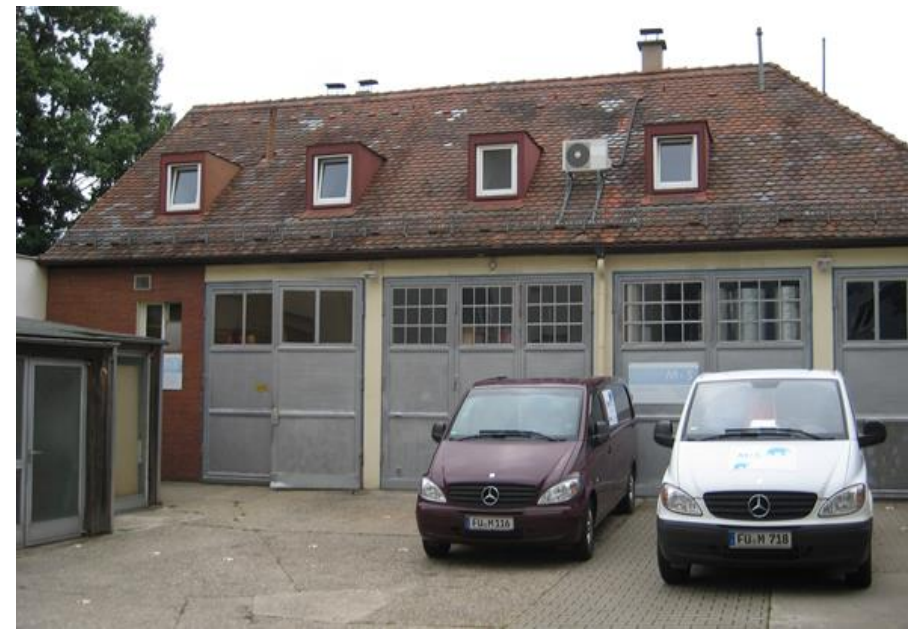

Fig.1. It all began in a garage

Source: Author's illustration

The beginnings in the winter of 1991 were modest to the extreme. The duo produced their first pastries in a double garage in Stein (Figure 1), Franconia, in an area of just 50 square metres. The equipment was limited to a kneader, a pastry roller and a small croissant machine. But it was at this crucial time that Erwin Wolf and Dagmar Kreis defined three decisive quality features which have remained at the heart of Wolf ButterBack's philosophy to this very day: the exclusive use of best pure butter, the careful artisan approach to production and the long resting times to achieve maximum natural freshness and full flavour. Initially, the two pioneers were ridiculed by their competitors, but this did not deter them. The enthusiasm of their customers proved them right. After just one year, they went in search of larger premises to cope with the surge in order volumes. The rapid growth continued unabated with production spreading to three locations in the Nuremberg region by 1999.

\subsection{Modernising Into the Future}

With further growth on the cards, Erwin Wolf and Dagmar Kreis who was appointed managing director in 1998, decided to invest in the construction of a new facility. On 1 August 2000, Wolf ButterBack moved into its first privately owned premises in Magazinstraße Fürth, equipped with highly technical production systems, 
a high-bay warehouse and state-of-the-art equipment. This fast-paced success story was overshadowed by a tragic accident in the summer of 2002. A passionate paraglide Dagmar Kreis, was sadly involved in a paragliding crash and died at the scene. Robbed of his designated successor, Erwin Wolf decided to sell the company in 2004, at the age of 67 . After just two years at its new home, the company was already nearing full capacity, making an extension essential. As a result, the founder went in search of a buyer who not only had the necessary financial clout but who would also guarantee the continuation of Wolf ButterBack's unique and very special corporate culture. On 1 January 2004, Wolf ButterBack changed hands and became part of the Martin Braun-Group, whilst founder Erwin Wolf withdrew into a well-earned retirement. Today, he runs a livery stable Müllers Pferdeparadies in Hergatz, whilst following Wolf ButterBack's continued development with both interest and enthusiasm.

In the Martin Braun-Group Wolf found the perfect balance between industrial expertise, financial power and the values of a long established, family-run business. The Martin Braun Group was 1990 taken over by the Oetker-Gruppe (Martin Braun-Gruppe 2013), and incorporated within the food division of the Oetker Group and comprises all the companies in the Oetker Group involved in "large-scale consumer baking". With more than 26,000 employees and sales of roughly EUR 11 billion, the Oetker Group is one of Europe's largest family-owned companies. Dr. August Oetker KG acts as the holding company of the Oetker Group, an internationally active company founded over 100 years ago broadly diversified in six operating divisions with a total of more than 400 companies worldwide. The Food division of the Oetker Group spans various food company brands as well as other companies operating in the institutional and bulk consumer segments. (Dr. August Oetker KG 2013)

\subsection{Continued Growth and Internationalisation}

In June 2005, large-scale construction work began on a second facility on the production site in Fürth which was completed in spring 2006. First-class product quality and fast, direct routes are of great importance, this is why they decided to group both production and administration in a single location in Fürth. Wolf ButterBack's premises cover a total area of $20,000 \mathrm{~m}^{2}$ (Figure 2).

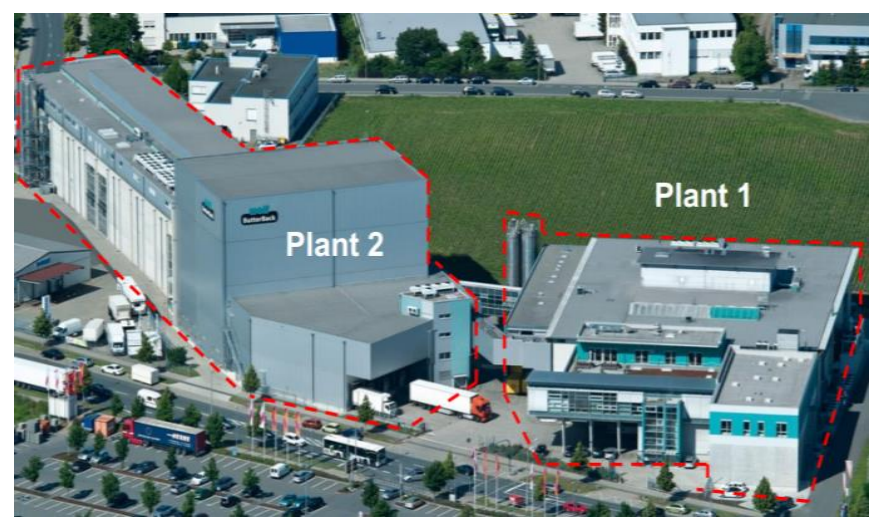

Fig.2. Production site in Fürth

Source: Wolf ButterBack

The office building encompassing the seminar room (baking studio), Plant 1 accommodating 12 production lines and Plant 2, completed in 2006 and extended in 2009, housing the donut line, 2 croissant lines and a computer-controlled cold storage high-bay warehouse for frozens with a capacity of 5000 pallets. The new complex was also designed with a computer-controlled high-bay cold storage warehouse for frozens, initially boasting a capacity of 2500 pallets, which was doubled to 5000 at the end of 2009. Annual production 2012: 25160 tons deep-frozen pastries $=252842270$ units (Kahler 2013). In addition, a storey was added to production and a new despatch and consignment area was created with a view to maximising the flexibility of all deliveries. They supply customers through the BAKO cooperatives (Germany and Austria) and selected wholesalers. In the 1990s Wolf ButterBack started supplying customers in other European countries. Today, Wolf ButterBack operates across 16 countries, including Japan, Estonia and Russia, partnership with exclusive resellers (Kahler 2013). In Austria, Italy, Spain, the Czech Republic, France, Turkey, Poland and Hungary, Wolf ButterBack is represented either by its own sales staff or by agents associated with the Martin Braun 
Group. Although Wolf ButterBack has acquired a truly international flavour, it has still remained a German company: Its production is located solely in Fürth, whilst its ingredients are almost all from the region or from within Germany's borders.

\subsection{Sustainable Management Has a Long Tradition at Wolf ButterBack}

Sustainable management became an unwritten law at Wolf ButterBack in the early days and is something they have been practising on a day-to-day basis ever since. In keeping with the family-run Oetker Group, their entrepreneurial vision has never only focused on short-term profit maximisation but always on the company's long-term survival. Accordingly, the company's interests have always come first, receiving priority over those of its owners. Over the years, they have consistently sought to build on the values created by maximising reliability and striving for sustainable management in all fields.

They believe that the question of sustainability is closely interwoven with the unrelenting commitment to high quality. The vision of sustainability is holistic in its approach, as they strive for a healthy balance between business targets, the need for realistic environmental and climate protection, optimum customer service, fair treatment of staff, and making an active and meaningful contribution to our society. They see sustainable management as an obligation to their customers, staff, suppliers, and people in their region - to society as a whole. They also believe that sustainability gives them a unique opportunity to rise above the crowd in a world that is increasingly characterised by brutal competition (e.g. Klemme AG, Hiestand Schweiz AG) (Kahler 2013; Möricke 2013; Prause, Hunke 2014; Dudzevičiūtè 2013; Tvaronavičienè 2014). They subject the suppliers of their ingredients to a strict selection process as well as regular checks. Moreover, they never lose sight of our environmental responsibility, preferring to use local ingredients in a move to minimise food miles.

The following six areas are at the heart of the sustainable management programme: 1) Identifying customer wishes, finding holistic solutions; 2) Diversity and success through innovation; 3) Committed to holistic quality; 4) Active environmental and climate protection; 5) Staff: high performance through diversity; and 6) Contributing to a fair society (Mit tradition und... 2011). The question of sustainability and regionalism is something that they practice as well as preach. Ever since the early days, they have been making and distributing the finest bakery products from a single production and administration facility in Fürth/Nuremberg. This aspiration is also reflected in their choice of suppliers and raw materials. As a result, more than $90 \%$ of the raw materials they use originate from Germany and Austria, with as much as $25 \%$ coming from within a 100km radius of our facility (e.g. Wiesneth Mill, H. Gugel GmbH, Bayernland eG, Adolf Darbo AG). This is a testament to Wolf ButterBack's commitment to their region. Also, a small carbon footprint not only lessens our impact on the environment but short transport routes are also an important quality criterion for freshly made products.

Our society is becoming increasingly aware of a somewhat unsettling trend: More and more companies are replacing full-time jobs with badly paid or even unpaid traineeships that are snapped up by graduates seeking their first career challenge. In doing so, these companies play on the insecurities and hopes of young people as they strive to find responsible and permanent employment that offers them a perspective. More often than not, their hopes are dashed, as one trainee follows the next. In some sectors, this has become common practice. Karriere.de singles out companies that take a responsible stance towards the staff of the future by awarding them the "Fair Company" title, this title has been presented to Wolf Butterback because they give students and graduates a real chance. After all, sustainability conceals a diversity of new business opportunities which can also have a pleasant impact on our wallets.

Structure follows strategy, changes in corporate strategy lead to changes in organizational structure. In view of stages of corporate development WBB is in the III stage - divisional structure. This allows management of diverse product lines in numerous industries, and decentralized decision making. This multidivisional structure is built up of separate divisions on the basis of geographical areas. Control by performance, ownership of strategy, and training in strategic view is advantageous. Main disadvantages might be duplication of central and divisional functions, and danger of loss of central control. Members of the board of directors are Axel Dirschner Authorised Officer / Director of Finance and Administration, Since 1 June 2012 Christian Tomasch (47) Spokesman of the Board of Managing Directors / Director of Sales and Marketing, and Ernst Stengel Authorised Officer / Director of Production and Procurement. 
More than 530 highly motivated WBB colleagues, about 460 of them in the production (Kahler 2013). Currently 27 representatives taking care of customers in Germany 15 sales representatives, Austria, 5 sales representatives, Italy, 4 sales representatives, France 1 sales representative, Benelux countries on sales representative, Great Britain \& Ireland 1 trade representative, Turkey/Hungary/Poland distribution via Martin Braun national companies, Northern and Eastern Europe 1 sales representative, Balkan states 2 sales representatives, other countries / overseas export + distribution partner (Kahler 2013).

\subsection{Values Are the Heart and Soul of the Company}

Even after nearly two decades of strong growth, the values that were the heart and soul of the company in that tiny garage in Stein are still valid today: Passion for the highest quality, focus on what is important and sustainable and, above all, closeness to customers. Wolf ButterBack's understanding of quality is not only reflected in products but it also permeates everything they think and do on a daily basis. They have a very holistic grasp of quality: "in our view, quality covers all aspects, from the careful selection of only the best ingredients and our artisan approach to production, to our comprehensive range of services and the continuous development of innovative and delicious bakery products" (Kahler 2013). To achieve maximum freshness and full flavour, they only use best pure butter in the production of choice pastries and deep-fried donuts. The sweet and savoury fillings are predominantly based on own, tried-and-tested recipes. Combined with state-ofthe-art machinery, the used production method enables customers to benefit from high and consistent levels of quality. Wolf ButterBack allows the dough to rest for a long period of time prior to processing, enabling bakery products to develop their full flavour, and enhance the taste of the pastries. Bakery products are very labourintensive, employing a high number of trained and highly skilled bakers. Pastries and donuts are produced in many complex stages and require a high level of skill and craftsmanship. The high quality of Wolf ButterBack products is a reflection of the many handmade stages in the production process. They achieve a high degree of uniformity by bringing the pastries into their final shape by hand. The majority of fillings are home-made following our own recipes.

As a member of the Oetker Gruppe, they comply with the guidelines of the Dr. Oetker Food Standard. The production facility has been certified by independent German testing institute TÜV since 2007 in compliance with the IFS (International Food Standard). In 2011, they were awarded IFS "higher level" certification achieving an impressive score of 98\%, which we then went on to raise in 2012 and 2013. In 2009, they were the first company in sector to be successfully awarded TÜV SÜD certification for excellent customer services in conjunction with maximum customer satisfaction. They apply particularly stringent quality criteria in the selection of ingredients. These criteria are under constant scrutiny to ensure that they comply with new regulations, the latest scientific findings and own experience. Quality criteria that are currently in place are: Maximum transparency, local ingredients, no use of genetically modified ingredients, no imitation or substitute foods, reducing the use of additives, avoiding aromas, avoiding allergens, avoiding acrylamide, minimising trans fatty acids (TFA), and avoiding hydrogenated fats.

Wolf ButterBack's standard range of croissants, sweet filled pastries, snacks, mini pastries, ball donuts, American bakery, laugen products, and speciality breads comprises over 150 different items, with innovative new products being added every year. Instead of adapting innovations to technical capabilities, they modify the machinery to meet the demands of new products. This gives them maximum flexibility and allows reacting swiftly to emerging trends. Be it ready-to-bake or unproved, ready-baked or pre-baked, Wolf ButterBack's products are made to various levels of convenience. This makes them suitable for different purposes and conditions on-site.

The dynamic sales team in Fürth provides 27 representatives taking care of customers, with all the support they need in giving customers, and the best possible service and in answering all questions. No two companies are the same. Every enterprise faces its own challenges, sets its own targets and has its own needs. This is why Wolf ButterBack tailors its seminars to individual needs. Assistants, who treat each customer individually by taking their wishes and needs into consideration, can make a meaningful contribution to stimulating sales. Group games and role plays are based on practical examples and will prepare you to engage in pro-active selling. 


\section{Conclusions and Recommendations}

The Wolf ButterBack case was especially designed for using the Wheelen and Hunger (2012) case method, providing the opportunity to move from a narrow, specialized view that emphasizes functional techniques to a broader, less precise analysis of the overall corporation. Its strengths include a real-world orientation and the ability to focus on developing decision-making skills.

The strategic audit should start with a careful reading of the Wolf ButterBack case, then reading the case again with the strategic audit worksheet. Next step is starting doing outside research, calculating common size financial statements, and key ratios, if appropriate. Here also describing the basic corporate governance mechanisms of the corporation. Owners and managers are the people who are primarily tasked with the strategic management process if the corporation is to have long-term success in accomplishing its mission. The advanced SWOT analysis starts with the external (EFAS), and internal (IFAS) factor analysis, concluding in a comprehensive strategic factor analysis summary (SFAS). After working out strategic alternatives and recommendations, an implementation, evaluation and control process of organisational learning is following. Organizational success is related to growth and development.

It is recommended that further research should include evolutionary approaches, which are not explicitly used as a theoretical framework in strategic management, although the evolutionary perspective is consistent with it. The case study is limited by the lack of financial information; this is typical for family owned firms where statements are delivered only to family members.

This case study confirms the importance of value based sustainable entrepreneurship. Sustainable management is still an unwritten law at Wolf ButterBack and is something they have been practising on a day-to-day basis ever since. Their entrepreneurial vision has never only focused on short-term profit maximisation but always on the company's long-term survival. The values that were the heart and soul of the company in that tiny garage in Stein are still valid today: Passion for the highest quality, focus on what is important and sustainable and, above all, closeness to customers.

Strategic management has become a major topic in the world of business, politics, and academia throughout the world. It has important implications not only for business, but for the wider economy and society.

\section{References}

Dr. August Oetker KG. 2013. Available from: 〈http://www.oetkergruppe.de〉. (Assessed 18 November 2013)

Dudzevičiūte, G. 2013. Lithuanian manufacturing trends in the context of developed and developing countries, Entrepreneurship and Sustainability Issues 1(1): 55-66. DOI: http://dx.doi.org/10.9770/jesi.2013.1.1(6)

Kahler, B. 2013. August 27. Interview by M. Wahl. Positionierung und Strategie der Wolf Butterback KG.

Korsakiene, R. 2013. Internationalization of construction firms: what strategy do they follow?Entrepreneurship and Sustainability Issues 1(2):99-107. DOI: http://dx.doi.org/10.9770/jesi.2013.1.2(4)

Korsakienè, R.; Tvaronavičienė, M. 2014. Processes of economic development: case of Lithuanian real estate sector,Entrepreneurship and Sustainability Issues 1(3): 162-172. DOI:http://dx.doi.org/10.9770/jesi.2014.1.3(5)

Laužikas, M.; Krasauskas, A. 2013. Impacts of sustainable structural growth on the economic performance of listed companies, Entrepreneurship and Sustainability Issues 1(2): 81-91. http://dx.doi.org/10.9770/jesi.2013.1.2(2)

Laužikas, M.; Mokšeckienè. 2013. The role of creativity in sustainable business, Entrepreneurship and Sustainability Issues 1(1): 1022. DOI: http://dx.doi.org/10.9770/jesi.2013.1(2)

Martin Braun-Gruppe. 2013. Available from: <http://www.martinbraungruppe.de>. (Assessed 12 December 2013)

Mit Tradition und Verantwortung in die Zukunft: Nachhaltigkeitsbericht 2011 der Wolf ButterBack KG. 2011. Fürth: Wolf

Butterback KG. Available on the Internet:

<http://www.butterback.de/fileadmin/butterback_repository/Divers/Nachhaltigkeitsbericht_2011_01.pdf>. 
Möricke, G. 2013. August 27. Interview by M. Wahl. Fachkräfte aus dem Bäckerhandwerk und Qualitätsphilosophie der Wolf Butterback KG.

Nickerson, J.; Yen, C.J.; Mahoney, J.T. 2012. Exploring the Problem-Finding and Problem-Solving Approach for Designing Organizations, Academy of Management Perspectives 26(1): 52-72.

Prause, G.; Hunke, K. 2014. Sustainable entrepreneurship along green corridor, Entrepreneurship and Sustainability Issues 1(3): 124133. DOI: http://dx.doi.org/10.9770/jesi.2014.1.3(1)

Tvaronavičienè, M. 2014. If industrial sector development is sustainable: Lithuania compared to the EU, Entrepreneurship and Sustainability Issues 1(3):134-142. DOI: http://dx.doi.org/10.9770/jesi.2014.1.3(2)

Wahl, M.; Prause, G. 2013. Toward understanding resources, competencies, and capabilities: business model generation approach, Entrepreneurship and Sustainability Issues 1(2): 67-80. DOI: http://dx.doi.org/10.9770/jesi.2013.1.2(1)

Wheelen, T.L.; Hunger, J.D. 2012. Strategic management and business policy, toward global sustainability. $13^{\text {th }}$ edition. New Jersey: Prentice Hall.

Wolf ButterBack. 2013. Available from: <http://www.butterback.de> (Assessed 16 November 2013)

Mike WAHL, Associate Professor, PhD from Tallinn School of Economics and Business Administration, Tallinn University of Technology is interested in Food Sciences, Management of Enterprises, and Corporate Governance. 